Fawaz F. Al-Bakri

Lecturer

Technical Institute of Babylon Al-Furat Al-Awsat Technical University

Hasan H. Ali

Lecture

Directorate of Reconstruction and Projects Ministry of Higher Education and Scientific Research

\section{Salwan Obaid Waheed Kafaj $i$ \\ Assistant Professo \\ University of Babylon \\ College of Engineering, Mechanica Engineering Department}

\title{
A New Analytical Control Strategy for a Magnetic Suspension System under Initial Position Dispersions
}

A nonlinear magnetic suspension system is considered in this paper. A novel online algorithm based on analytical approach is presented to stabilize the suspended mass. The new algorithm employs a single analytical function to create the ball position and velocity profiles. The reference ball position is described by a series of time dependent exponential functions. Boundary conditions at both initial and final states are automatically satisfied. Moreover, feasible ball position and velocity profiles are ensured by evaluating one algorithm parameter (an exponential factor). The exponential factor is analytically computed by minimizing the peak of electrical power. This new algorithm is capable of generating the well-suited coil voltage that guarantees the stability of the system with a small closed-loop command. Gain Shechting method is used to obtain the closed-loop effort in order to track the analytical reference profiles. Compared to the prior magnetic suspension algorithms, the proposed analytical scheme is qualified to handle very large dispersions in initial ball position while satisfying the ball position and coil voltage constraints. Monte-Carlo simulations with change in initial ball position are presented. The simulation results demonstrated the great reliable performance of the proposed algorithm despite the wide range of initial ball position dispersions.

Keywords: Analytical control, magnetic suspension system, initial position dispersion Monte-Carlo simulation.

\section{INTRODUCTION}

Substantial reduction in friction that exists between moving surfaces can be achieved using magnetic suspension systems which improves the efficiency of these systems. The magnetic suspension technology can be used in the transportation, environmental, aerospace, electrical, biomedical, and advertising engineering. A wide range of applications of magnetic suspension system is found in the literature such as wind turbines $[1,2]$, magnetic bearings $[3,4]$, and superconductor rotor suspension of Gyroscopes [5,6]. Various control strategies have been used with the goal of maintaining the suspended object in the desired height. In [7], a controller was designed for a magnetic suspension system based on a nonlinear model. Proportional-Integral (PI) adaptive robust controller that considers parametric uncertainty was presented in [8]. In [9], feedback linearization control was presented. A robust two degrees of freedom controller was designed in $[10,11]$ that takes in consideration the parametric uncertainty of the system. In [12], H-infinity controller was designed for a magnetic suspension system in a gantry-moving type numerically controlled machine tool. The results showed that the system has good stability and robustness charac-

Received: March 2021, Accepted: September 2021

Correspondence to: Dr. Salwan Obaid Waheed Khafaji

College of Mechanical Engineering,

University of Babylon-Mechanical Eng. Dep. Iraq

E-mail: eng.salwon.obaid@uobabylon.edu.iq

doi: $10.5937 /$ fme2104977F

(C) Faculty of Mechanical Engineering, Belgrade. All rights reserved teristics. An experimental study of an electromagnetic suspension system was presented in [13]. The results demonstrated that the loss generated by the current induced by the magnetic flux depends on the characteristics of current and the levitation gap.

Recently, the magnetic suspension system is greatly employed to consider the aircraft aerodynamic characteristics using the wind tunnel test. In [14], an active magnetic bearing mathematical model relying on L $\infty$ gain and PID controllers of an electric aircraft was presented. The proposed control was designed to cope the flight disturbance due to aircraft maneuvering. Finally, numerical simulations with and without maneuvering loads were conducted to perform the effectiveness of the presented method. The stability and performance issues caused by the aircraft maneuvering flight were studied in [15]. A mathematical model was created and a feed forward L-infinity gain controller was designed. The results of the proposed controller were compared to PID controller and showed stability and performance improvements. In [16], a suction-type su-personic wind tunnel magnetic suspension system was investigated. A proportional-integral (PI) controller alo-ng with a double-phase advancer was used to increase the response speed of the system. The results indicated that the system performs well when the appropriate values of frequency and moment of inertia are used. The persistent current of a magnetic system superconducting coil for a suspended object such as an aircraft was studied in [16]. PID controller was used and the statics and dynamics of the suspended object were 
studied. The results showed that there is a limit for the persistent current which is a function of the density of the vertical magnetic flux. In [17], bent sting and external model support interference types for a subsonic wind tunnel were considered. The author prepared conditions that resemble real conditions in order to overcome the differences between the flow around a test model and real aircraft. The results illustrated that the numerical and experimental results were congruent, which indicates the effectiveness of the proposed algorithm to compute reliable aerodynamic coefficients. In [18], a magnetic and balance system that allows suspending an object in subsonic flow condition was studied. PI and PID cont-rollers were used. The results demonstrated that a cylin-drical object of $10 \mathrm{~mm}$ diameter and $156 \mathrm{~mm}$ length could be suspended at Mach number up to 0.6. In [19] and [20], a system of control of measurements in the T-35 $4.4 \mathrm{~m} \times 3.2 \mathrm{~m}$ and VTI's subsonic wind tunnels was instituted and ensured. The measurements performance was assured based on three parameters; wind tunnel calibration, instrumentation calibration, and wind tunnel periodic tests. The results performed well-suited measu-rements compared with a relevant wind tunnel type. In [21], aerodynamic coefficients were computed using six transonic wind tunnels at three Mach number values; $0.77,1$, and 1.17. The results showed that the zero-lift drag coefficient at sonic Mach number was better than other Mach values. In [22], the effect of hot combustion products on a CFD model was considered. The missile aerodynamic loads were computed using finite volume method. The experimental and numerical results of the missile aerodynamic coefficients were proposed and compared as well.

Despite recent works consider numerical or optimal methods to stabilize the magnetic suspension system, some of them are too complicated to be implemented in a real time, while other prior studies cannot adequately handle wide dispersions of initial conditions. Hence, it is important to discover a new algorthim that can stabilize the magnetic suspension system in a real time in the presence of wide initial conditions dispersions.

This work introduces a novel online algorithm to stabilize the magnetic suspension system analytically. The new algorithm uses a single analytical function, a six-term exponential function with time as the independent variable to shape the reference ball position and velocity profiles. The tracking reference profiles are obtained by selecting one free variable, the exponential factor while minimizing the peak of electrical power. Since the proposed exponential function provides a congruent reference ball position with the actual profile, the reference coil voltage can guarantee stability of the system with small control effort. The closed-loop simulation is designed using the gain scheduling method. The Monte-Carlo simulation was used to demonstrate the effectiveness of the proposed algorithm by simulating the system under simultaneous large dispersions in initial ball position. Compared to prior works, the proposed algorithm ensures a remarkable ball position response, zero percentage overshoot, excellent damping, and fast response.

\section{SYSTEM MODEL}

As shown in Figure 1, the magnetic suspension system consists of the mechanical system (steel ball) suspended by the electromagnetic system (magnetic coil) as presented in (Khalil and Grizzle, 2002). It was assumed that the electrical system is a linear resistance- inductance (RL) circuit.

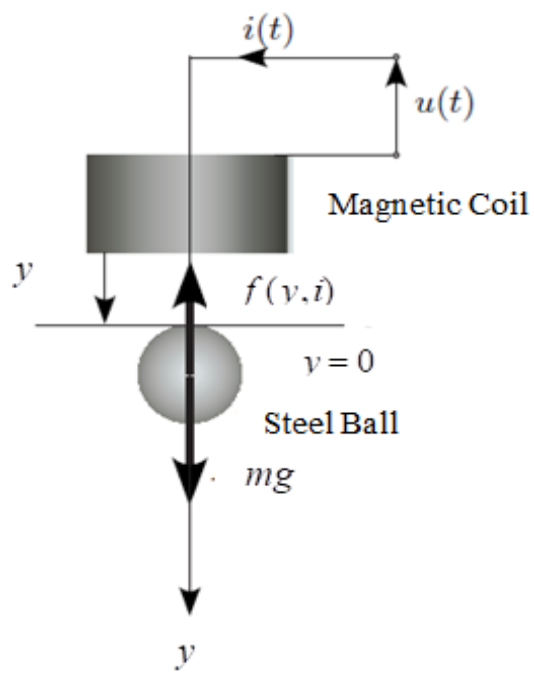

Figure 1: Magnetic Suspension System

where $m, g, R$, and $L$ are the suspended ball mass, gravitational acceleration, circuit resistance, and inductance of the electromagnetic circuit, respectively, $y$ is the position of the ball measured from a reference position $(y=0)$ and directed downward, $i$ and $u$ are the coil current and voltage, respectively, and finally $f(y, i)$ is the generated magnetic force.

The electromagnetic inductance of the system can be obtained as a function of the ball position,

$$
L(y)=L_{1}+\frac{a L_{0}}{(a+y)}
$$

where $L_{0}, L_{1}$ and $a$ are positive constants. Clearly, Eq. (1) shows that the inductance has a maximum value $\left(L=L_{1}+L_{0}\right)$ that is associated to the reference position (y $=0)$ while it has a minimum value $\left(L=L_{1}\right)$ that is associated to the ball downward position $(y=\infty)$. The inductance profile as a function of ball position is illustrated in Fig. 2.

The suspended ball motion can be modeled using Newton's second law,

$$
m \ddot{y}=-k \dot{y}+m g-f(y, i)
$$

where $k$ is the viscous friction coefficient. The energy of the magnetic coil can be easily obtained as follows,

$$
E(y, i)=\frac{1}{2} L(y) i^{2}
$$

The electromagnetic force can be computed by differentiating Eq. (3) with respect to the ball position,

$$
f(y, i)=\frac{L_{0} i^{2}}{2 a(1+y / a)^{2}}
$$




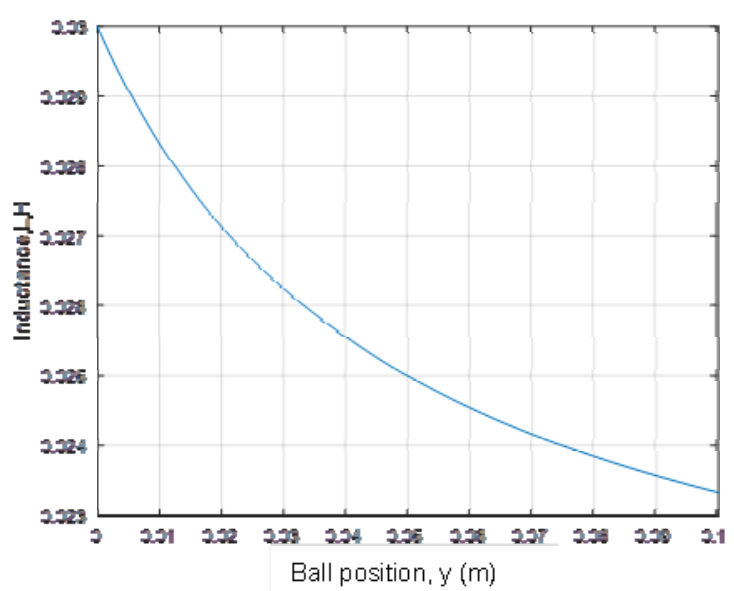

Figure 2: Electromagnetic inductance vs. ball position.

By applying the Kirchhoff's voltage law, the coil voltage $(v)$ is obtained,

$$
v=\dot{\phi}+R i
$$

where | is a magnetic flux linkage, which can be determined by,

$$
\phi=L(y) i
$$

The second and first order differential equations of the mechanical and electrical subsystems, respectively, can be written as three first-order differential equations by considering $X=\left[\begin{array}{lll}x_{1} & x_{2} & x_{3}\end{array}\right]=\left[\begin{array}{lll}y & \dot{y} & i\end{array}\right]$ as the system states and $u=i$ as the system input as follows,

$$
\begin{aligned}
& \dot{x}_{1}=x_{2} \\
& \dot{x}_{2}=g-\frac{k}{m} x_{2}-\frac{a L_{0}}{2 m\left(a+x_{1}\right)^{2}} x_{3}^{2} \\
& \dot{x}_{3}=\frac{1}{L\left(x_{1}\right)}\left(-R x_{3}+\frac{L_{0}}{\left(a+x_{1}\right)^{2}} x_{2} x_{3}+u\right)
\end{aligned}
$$

The state space representation (SSR) model can be utilized to obtain the three nonlinear differential equations a linear, time invariant model as:

$$
\dot{x}=A x+B u
$$

where

$$
A=\left.\sum_{i}^{n} \sum_{j}^{n} \frac{\partial f_{i}}{\partial x_{j}}\right|_{x=x^{*}, u=u^{*}}=\left[\begin{array}{ccc}
\frac{\partial f_{1}}{\partial x_{1}}\left(x^{*}, u^{*}\right) & \ldots & \frac{\partial f_{1}}{\partial x_{n}}\left(x^{*}, u^{*}\right) \\
\vdots & \vdots & \vdots \\
\frac{\partial f_{n}}{\partial x_{1}}\left(x^{*}, u^{*}\right) & \cdots & \frac{\partial f_{n}}{\partial x_{n}}\left(x^{*}, u^{*}\right)
\end{array}\right]
$$

where $A \in \mathbb{R}^{n \times n}$

$$
B=\left.\sum_{i}^{n} \sum_{j}^{m} \frac{\partial f_{i}}{\partial u_{j}}\right|_{x=x^{*}, u=u^{*}}=\left[\begin{array}{ccc}
\frac{\partial f_{1}}{\partial u_{1}}\left(x^{*}, u^{*}\right) & \ldots & \frac{\partial f_{1}}{\partial u_{m}}\left(x^{*}, u^{*}\right) \\
\vdots & \vdots & \vdots \\
\frac{\partial f_{n}}{\partial u_{1}}\left(x^{*}, u^{*}\right) & \cdots & \frac{\partial f_{n}}{\partial u_{m}}\left(x^{*}, u^{*}\right)
\end{array}\right]
$$

where $B \in \mathbb{R}^{n \times m}$

Then, the state space representation model of the proposed system for three states $(n=3)$ and one input ( $m$ $=1$ ) can be defined as:

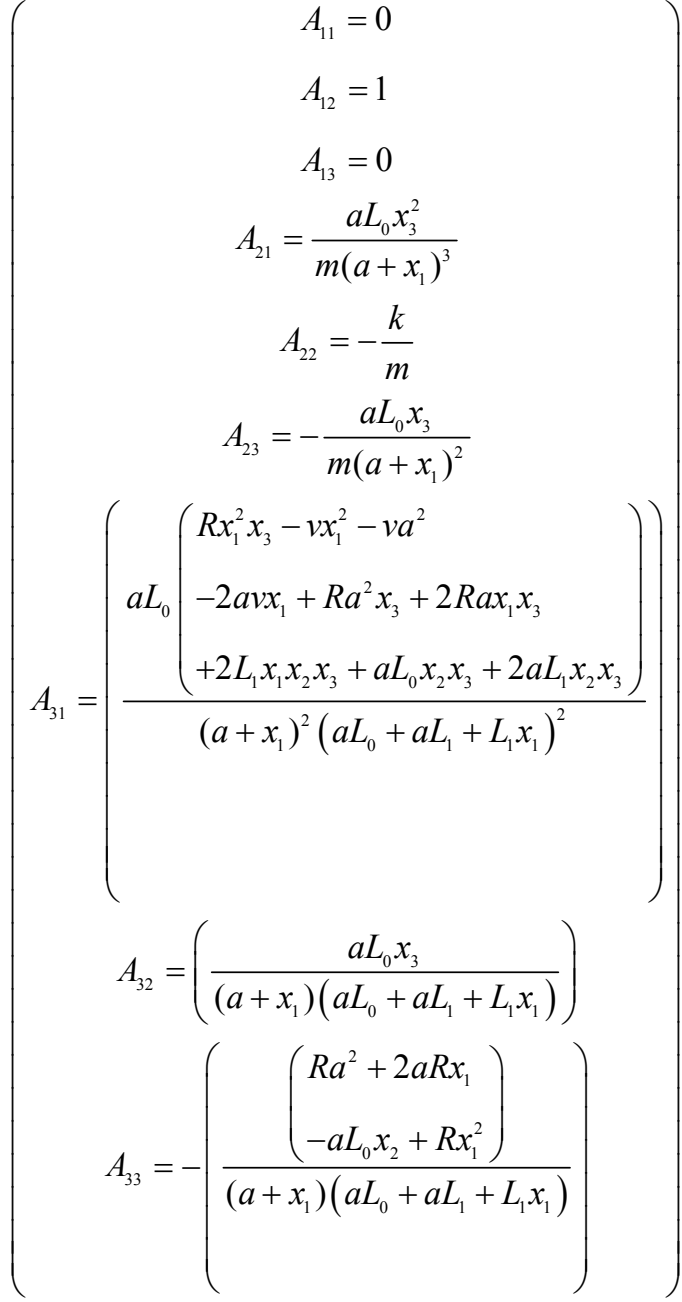

$$
\begin{aligned}
& B=\left[\begin{array}{c} 
\\
0 \\
0 \\
\frac{\left(a+x_{1}\right)}{\left(a L_{0}+a L_{1}+L_{1} x_{1}\right)}
\end{array}\right]
\end{aligned}
$$

It can be noted that the matrices are highly nonlinear in terms of the ball position, ball velocity, coil current, and as well as the coil voltage, while other system parameters are constants which values are given in Table 1 [23].

Table 1: Mechanical and Electrical System Parameters

\begin{tabular}{|l|c|}
\hline Parameter & Value \\
\hline Ball mass $(\mathrm{kg})$ & 0.1 \\
\hline Viscous friction Coefficient, $\mathrm{k},(\mathrm{kg} / \mathrm{s})$ & 0.001 \\
\hline Gravity acceleration, $\mathrm{g},\left(\mathrm{m} / \mathrm{s}^{2}\right)$ & 9.81 \\
\hline Constant, $\mathrm{L}_{0},(\mathrm{H})$ & 0.01 \\
\hline Constant, $\mathrm{L}_{1},(\mathrm{H})$ & 0.02 \\
\hline Constant, $\mathrm{a},(\mathrm{m})$ & 0.05 \\
\hline Circuit resistance, $\mathrm{R},(\mathrm{Om})$ & 1 \\
\hline
\end{tabular}

\section{ANALYTICAL ALGORITHM}

The main goal of magnetic suspension system algorithms is to stabilize the suspended mass targeting the desired position and velocity profiles. Generally, the algorithm requires two basics: creating a reference 
trajectory, and then designing a closed-loop command in order to track the shaped reference trajectory. In most suspension systems such as [23], a steady-state condition, which assumes all the states (ball position, ball velocity, and coil current) are constant, is used to generate a reference trajectory. First, a steady state ball position value is selected, and then the rest states and input are computed based on this adopted position. However, in this work, the reference trajectories: the ball position, ball velocity, coil current, and coil voltage are shaped analytically after selecting a single free variable. The proposed algorithm utilizes a single analytical function to generate the ball position profile. This reference position is parametrized by a six-term exponential function of time,

$$
y_{\text {ref }}=\sum_{n=1}^{6} c_{n} \exp (-\varepsilon n t)=x_{i}
$$

Taking the derivative of Eq. (13) with respect to time produces an expression for the reference magnetic suspension velocity profile

$$
\dot{y}_{\text {ref }}=(-\varepsilon n) \sum_{n=1}^{6} c_{n} \exp (-\varepsilon n t)=x_{2}
$$

Similarly, an expression for the reference suspended ball acceleration profile can be determined by taking the derivative of Eq. (14) with respect to time,

$$
\ddot{y}_{\text {ref }}=\varepsilon^{2} n^{2} \sum_{n=1}^{6} c_{n} \exp (-\varepsilon n t)
$$

Substituting Eqs. (13), (14), and (15) into Eq. (8) and solving the resulted equation for $i$, the reference coil current is obtained as shown in Eq. (16).

$$
\left.\left.i_{\text {ref }}=\left.\left(\frac{\left(\left(\frac{\left.\varepsilon^{2} n^{2} \sum_{n=1}^{6} c_{n} \exp (-\varepsilon n t)\right)}{\left(\frac{k}{m}\left((-\varepsilon n) \sum_{n=1}^{6} c_{n} \exp (-\varepsilon n t)\right)-\right.}\right)\right.}{2 m\left(a+\sum_{n=1}^{6} c_{n} \exp (-\varepsilon n t)\right)^{2}}\right)\right|_{3}\right)^{\frac{1}{2}}\right)^{2}
$$

In addition, substituting Eq. (1), (13), (14), (16), and the time derivative of Eq. (16) into Eq. (9) and solving for the voltage $(\mathrm{v})$ gives the reference coil voltage profile.

Thus, the reference electrical power can be defined as,

$$
P_{\text {ref }}=i_{\text {ref }} v_{\text {ref }}
$$

Six boundary conditions are required to evaluate the six coefficients, $c_{n}$. Here we used three pairs of suspended ball position, velocity, and acceleration at two time positions and solved the set of linear equations illustrated by Eqs. (13), (14) and (15). By definition, the magnetic suspended ball begins to move from rest at $t(=0)$; the initial ball position $\left(y=y_{0}\right)$, initial ball velocity $\dot{y}_{0}(=0)$, and initial ball acceleration $\ddot{y}_{0}(=0)$ are known parameters.

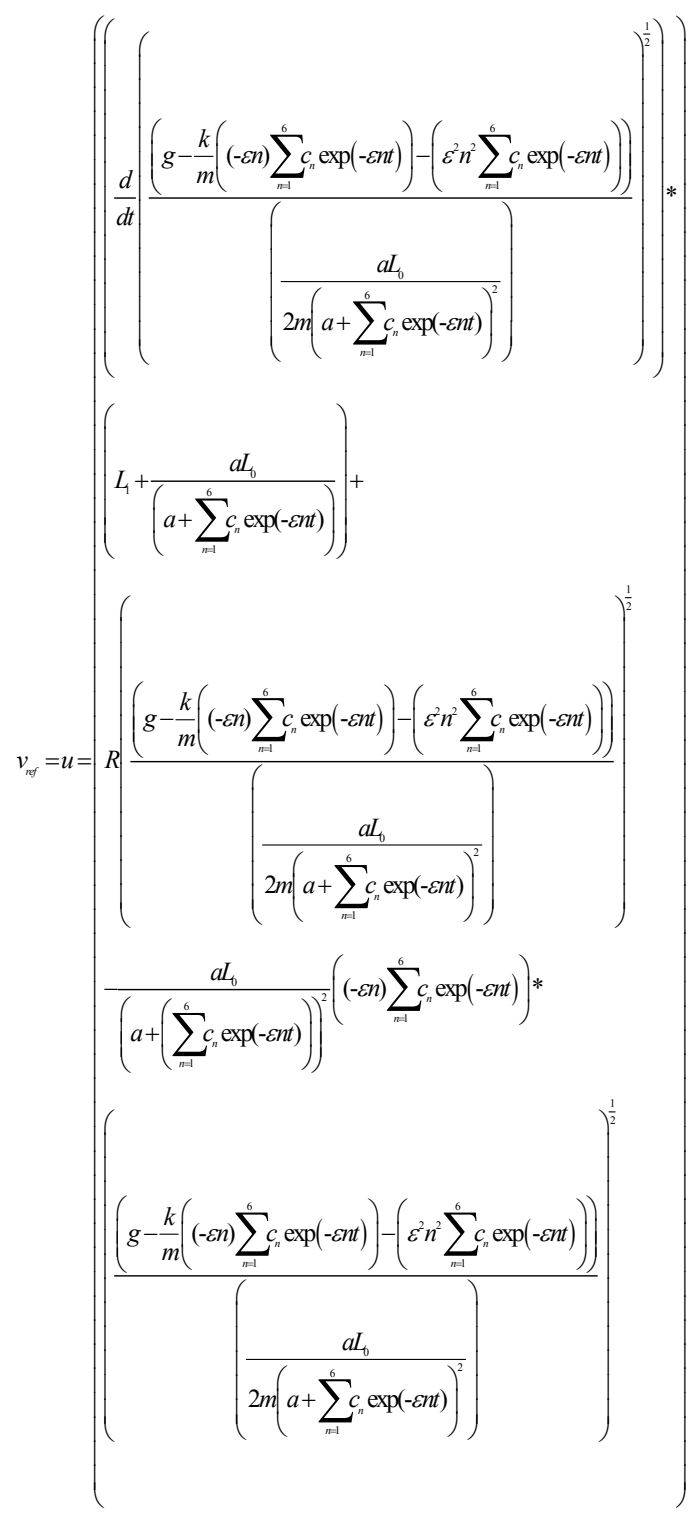

The system reaches steady-state condition at $t=0.6$ sec and its steady-state ball position $\left(y=y_{s s}\right)$, ball velocity $\dot{y}_{\mathrm{ss}}(=0)$, and ball acceleration $\ddot{y}_{\mathrm{ss}}(=0)$ are also known parameters. It important to mention that all the processes to solve the system of linear equations require a certain value of an exponential factor $(\varepsilon)$. A feasible reference position profile that guides the ball to the steady state condition and minimizes the peak of electric power was obtained by iteration on the exponential factor. It is unlikely that one exponential factor value confirms the minimum electric power peak that the system needs in order to move the ball from the initial state to the desired state. Therefore, the magnetic suspension system profile must be re-shaped by setting the exponential factor. To perform the process, consider the nominal initial and steady state ball positions are 0 $\mathrm{m}$ and $0.05 \mathrm{~m}$, respectively. Figure 3-a illustrates the reference ball position profiles for four values of 
exponential factor: $-0.5,-1.134,-1.767$, and -2.4 . Obviously, the trajectory with the largest value of $\varepsilon$ performs a short track while it follows a long track with selecting the smallest value of $\varepsilon$. Figure 3-b shows the electrical power computed analytically using Eq. (18). Figure 3-b shows that the short trajectory $(\varepsilon=-0.5)$ begins with the highest electrical power, while the long trajectory $(\varepsilon=-2.4)$ begins with the lowest electrical power (all trajectories end with the target electrical power at steady state point). Figure 3-b also shows that adopting exponential factor $\varepsilon=-1.83$ will shape the position profile so that the minimum peak of the electrical power profile is satisfied. The exponential factor, $\varepsilon$, is computed by a simple "brute-force" method: the minimum peak values of the electrical power were determined for a small number of trial for $\varepsilon$ and the minimum peak values are interpolated to hit the well-suited exponential factor that performs the lowest minimum peak. Six ball position trajectories were employed, and evaluating the proper $\varepsilon$ was ensured as long as the trials bracket the lowest minimum peak of the electrical power. Bracketing the desired minimum electrical power peak is obtained using six exponential factors in the range $-2.4<\varepsilon<-0.5$. Figure 4 shows the peaks of electrical power vs. the exponential factors for six trial position trajectories. The red point presents the correct exponential factor that produces the lowest minimum peak of the electrical power at the nominal conditions.

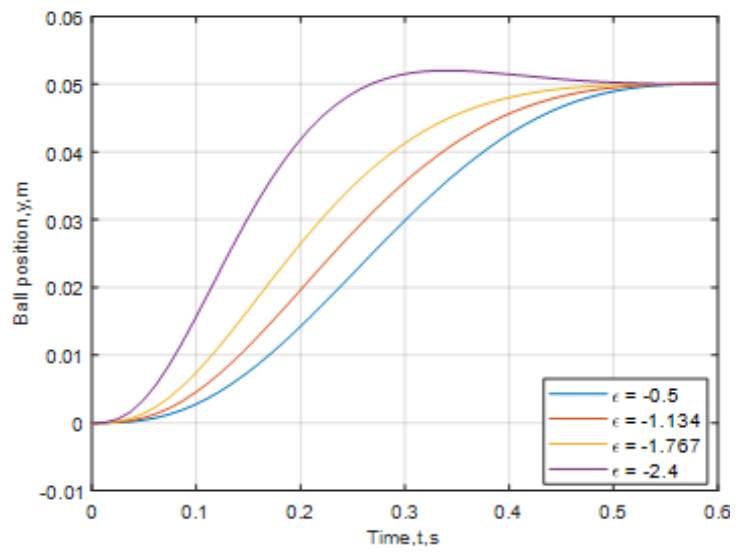

(a)

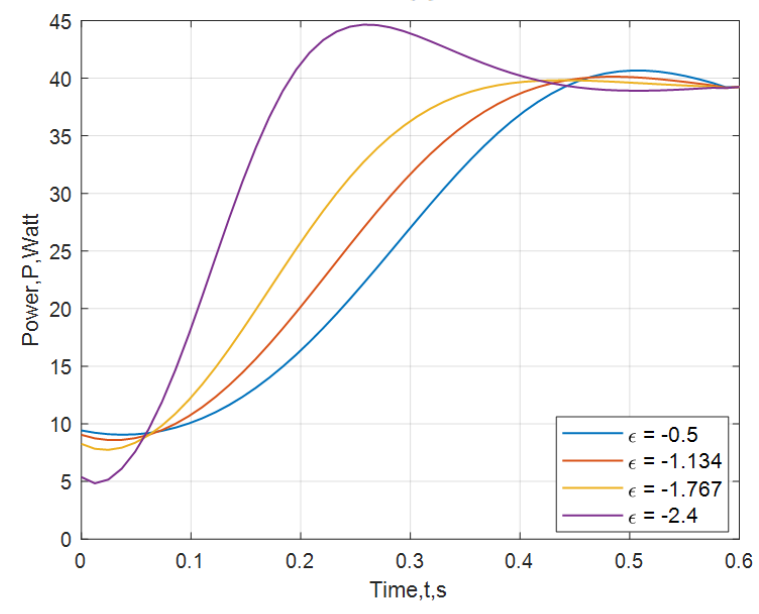

(b)

Fig 3. Re-shaping ball position profile by varying exponenttial factor $\varepsilon:$ a) reference ball position vs. time, b) reference electrical power vs. time.

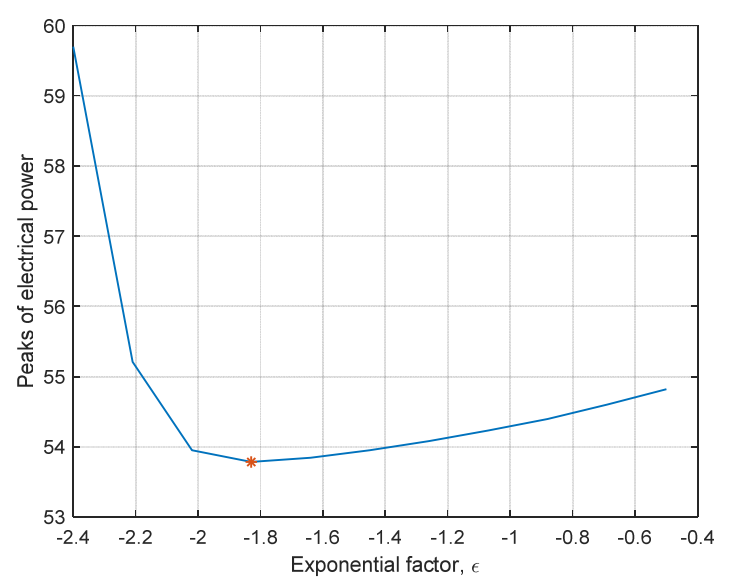

Fig.4 Brute-force method for six trial trajectories at nominal conditions.

\section{CONTROLLABILITY AND OBSERVABILITY COMPUTATIONS}

One of the important performance characteristics of a good control system is obtaining the controllability and observability of a linearized system. The system is linearized either around an equilibrium point or a reference trajectory. In this work, the reference trajectory is generated analytically after adjusting the exponential factor as previously described. The controllability and observability matrices of the system can be obtained as follows, respectively.

$$
\begin{aligned}
& C o=\left[\begin{array}{lll}
B & A B & A^{2} B
\end{array}\right] \\
& O=\left[\begin{array}{lll}
C^{\prime} & A^{\prime} C^{\prime} & A^{\prime 2} C^{\prime}
\end{array}\right]
\end{aligned}
$$

Substituting Eqs. (13-17) into Eqs. (11) and (12), A(t) and $\mathrm{B}(\mathrm{t})$ are obtained, respectively, as functions of time.

Then series of time dependent state space repre-sentations are substituted in Eqs. (19) and (20) to compute a set of controllability and observability matrices. Figu-res 5-a and 5-b show the determinant of controllability and observability matrices, respectively, for two initial ball positions, nominal value of $0 \mathrm{~m}$ and off-nominal value of $0.1 \mathrm{~m}$. Since the determinant values are not equal to zero, the linearized system has no singularity and all the controllability and observability matrices have full ranks. Thus the linearized model around the proposed reference trajectory for both nominal and off-nominal conditions is completely controllable and observable.

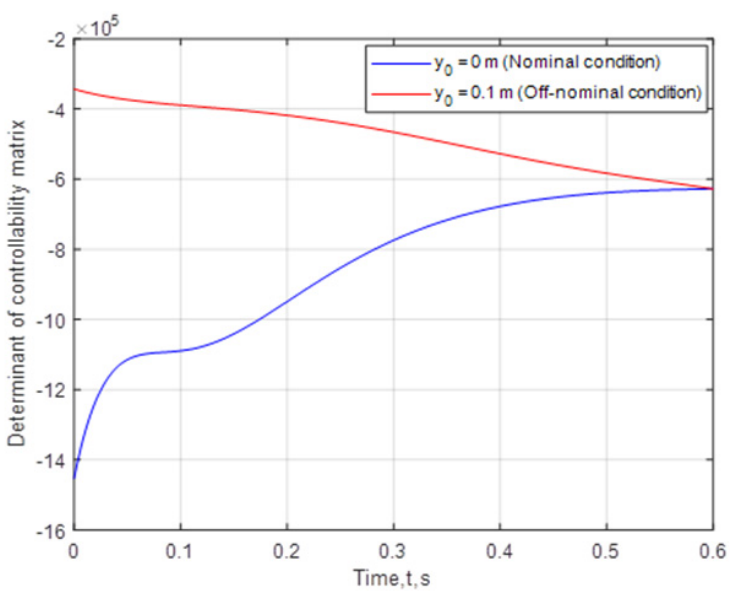

(a) 


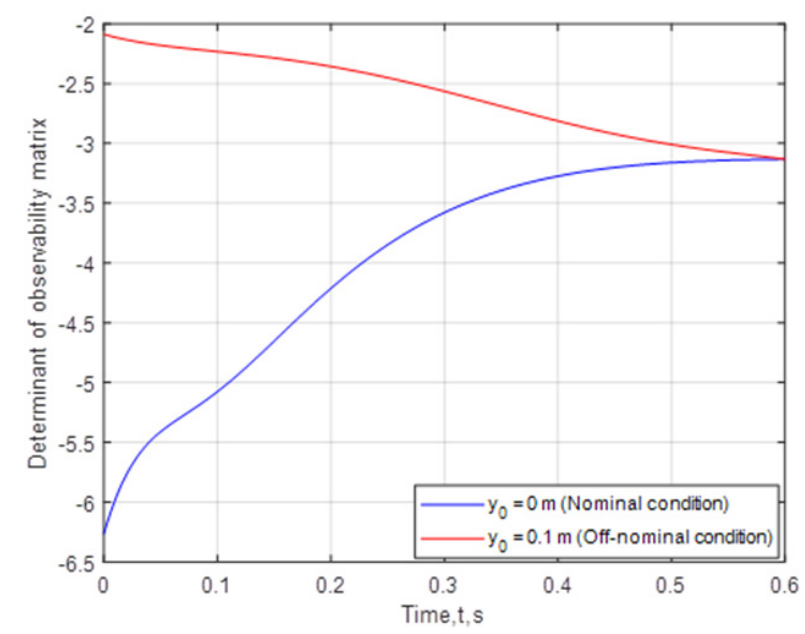

(b)

Figure 5. Controllability and observability computations for nominal $\left(\mathrm{y}_{0}=0 \mathrm{~m}\right)$ and off-nominal $\left(\mathrm{y}_{0}=0.1 \mathrm{~m}\right)$ conditions, respectively; (a) determinant of controllability matrices vs. time; (b) determinant of observability matrices vs. time.

\section{CLOSED-LOOP SIMULATION}

After generating the magnetic system references, ball position (Eq. 13), ball velocity (Eq. 14), coil current (Eq. 16), and coil voltage (Eq. 17), respectively, the closed-loop simulation is obtained to design the required control in order to track the shaped references and to stabilize the suspended mass. In this section, the influence of change of an initial ball position, nominal value of $0 \mathrm{~m}$ and off-nominal value of $0.1 \mathrm{~m}$ was considered. During the simulation, the closed-loop control law was used to model the coil voltage as follows,

$$
v_{r e f}+\delta v
$$

where $\mathrm{v}_{\text {ref }}$ is a reference coil voltage (computed using Eq. (16)), and $\delta v$ is a closed-loop feedback coil voltage which was computed using the closed-loop term,

$$
\delta v=-K_{y}\left(y-y_{\text {ref }}\right)-K_{\dot{y}}\left(\dot{y}-\dot{y}_{\text {ref }}\right)-K_{i}\left(i-i_{\text {ref }}\right)
$$

The closed-loop command tracks the ball position, ball velocity, and coil current to their respective profiles obtained based on the initial boundary condition of the ball position. The magnetic suspension system (the third-order system) has been linearized with respect to the reference trajectories and then the state gains $K_{y}, K_{\dot{y}}$ and $K$ a reobtained using pole-placement method. The three states of the linearized system are ball position, ball velocity, coil current while time is the independent variable. Since the linearized system is controllable along the proposed reference as seen in Fig. 4 (a), a consecutive of pole placement methods has been applied at discrete times to compute feedback gains that eventually can be scheduled with time. The closed-loop controller is designed so that the coil voltage does not exceed the voltage saturation value ( 15 Volt) as well the system performs a good damping and a fast response.

Figures 6 (a)-6 (e), show the ball position, ball velocity, coil current, coil voltage, and electrical power, respectively. These profiles were obtained for two initial ball positions, nominal value of $0 \mathrm{~m}$ and off-nominal value of $0.1 \mathrm{~m}$. As it can be seen from Fig. 6 (a) that the reference and closed-loop ball position profiles do not exceed the interval [ $\left[\begin{array}{ll}0 & 0.1\end{array}\right]$ and they belong to the term even with varying the initial ball position from 0 to $0.1 \mathrm{~m}$. Fig 6 (c) shows that the reference and closed-loop coil voltage profiles are limited between [ $\left.\begin{array}{ll}0 & 15\end{array}\right]$ Volt. All figures from 6 (a) to 6 (e) show that the ball position, ball velocity, coil current, coil voltage, and electrical power references are tracked very accurately with using the gain scheduling. This criterion indicates that the proposed algorithm is considered to be feasible and effective to stabilize the suspended mass under wide range of initial ball positions. As much as the proposed analytical function awards a conformable reference ball position to the actual profile, the reference coil voltage confirms remarkably the stability of the system with moderate closed-loop effort.

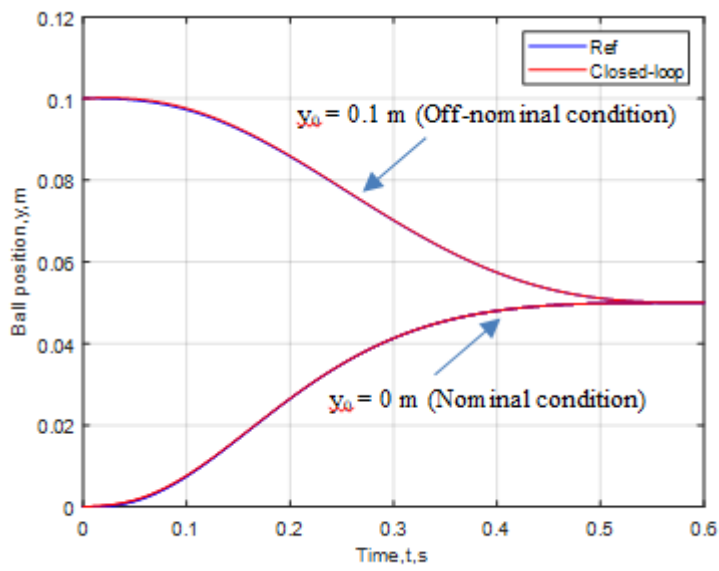

(a)

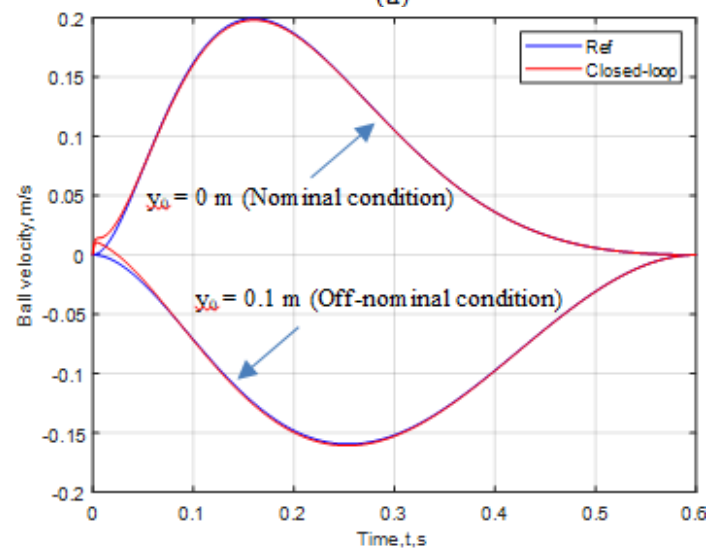

(b)

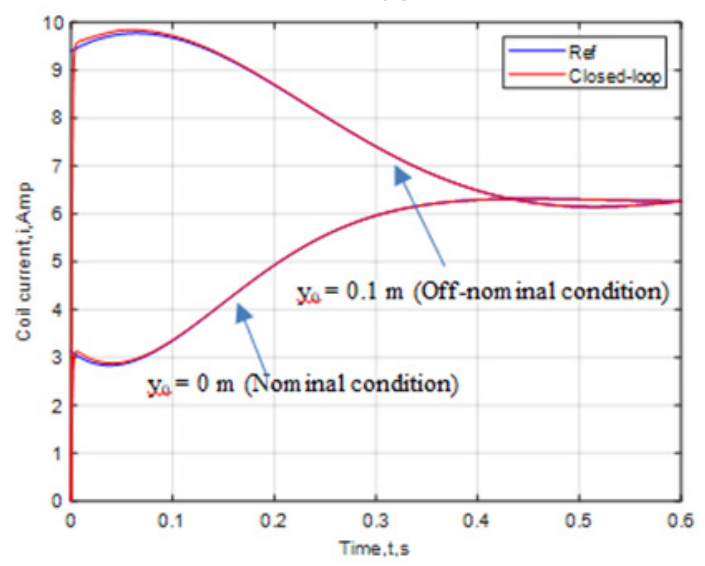

(c) 


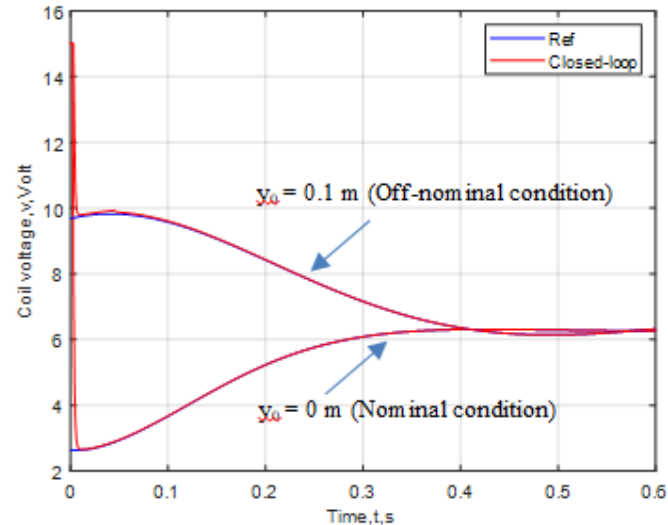

(d)

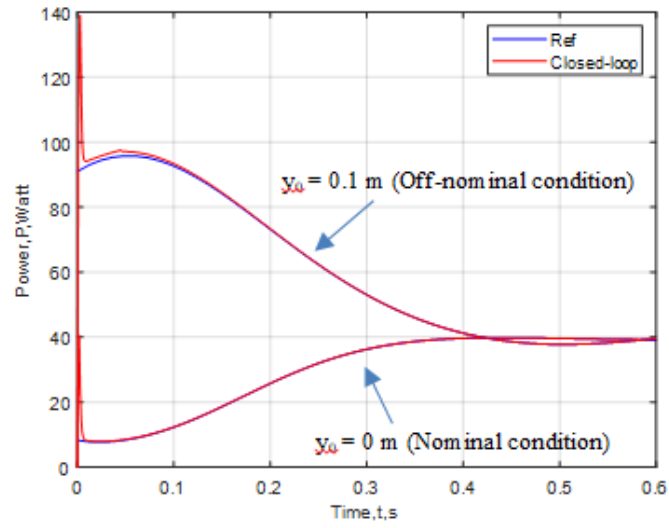

(e)

Figure 6. Reference and actual profiles for nominal $\left(y_{0}=0\right.$ $\mathrm{m})$ and off-nominal $\left(y_{0}=0.1 \mathrm{~m}\right)$ conditions, respectively; (a) ball position vs. time; (b) ball velocity vs. time; (c) coil current vs. time; (e) voltage current vs. time; (f) electrical power vs. time.

Compared to prior works, the steady state condition to create the reference profiles was used in [23] where $y_{s s}, \dot{y}_{s s}, i_{s s}$ and $v$ are $0.05 \mathrm{~m}, 0 \mathrm{~m} / \mathrm{s}, 6.265 \mathrm{Amp}$, and 6.265 Volt, respectively. The feedback gain vector was designed using the pole placement method with closed-loop eigenvalues of $-10,-10+\mathrm{j} 10$, and $10-\mathrm{j} 10$. The closed-loop was conducted at $t=1 \mathrm{~s}$ as the simulation time. Figures 7 (a) and 7 (b) show the actual ball position profiles with two initial ball positions $0 \mathrm{~m}$ and $0.07 \mathrm{~m}$, respectively. Both two position responses reach the desired reference position $0.05 \mathrm{~m}$ at steadystate point. In both figures, the current algorithm is successfully able to guide the suspended mass reaching the steady-state value of $0.05 \mathrm{~m}$ in about $0.52 \mathrm{~s}$, while suspended mass was stabilized in about $0.625 \mathrm{~s}$ by the prior work. The proposed work accepts a wide range of initial ball position between 0 and $0.1 \mathrm{~m}$ with satisfying the ball position constraints (as shown in Fig. 6 (a)). While the initial ball position was restricted to be between 0 and $0.07 \mathrm{~m}$ in the previous work.

In summary, the ball position response using the proposed algorithm has remarkably evolved: the overshoot is extremely low, the system exhibits a good damping and stability, and the steady-state time has effectively improved. However, it is unlikely to confidently implement the proposed algorithm relying on two initial ball positions. Therefore, Monte-Carlo Method with random initial ball positions limited between 0 and $0.1 \mathrm{~m}$ was obtained to demonstrate the effectiveness of the analytical algorithm under wide range of dispersions in the initial ball position.
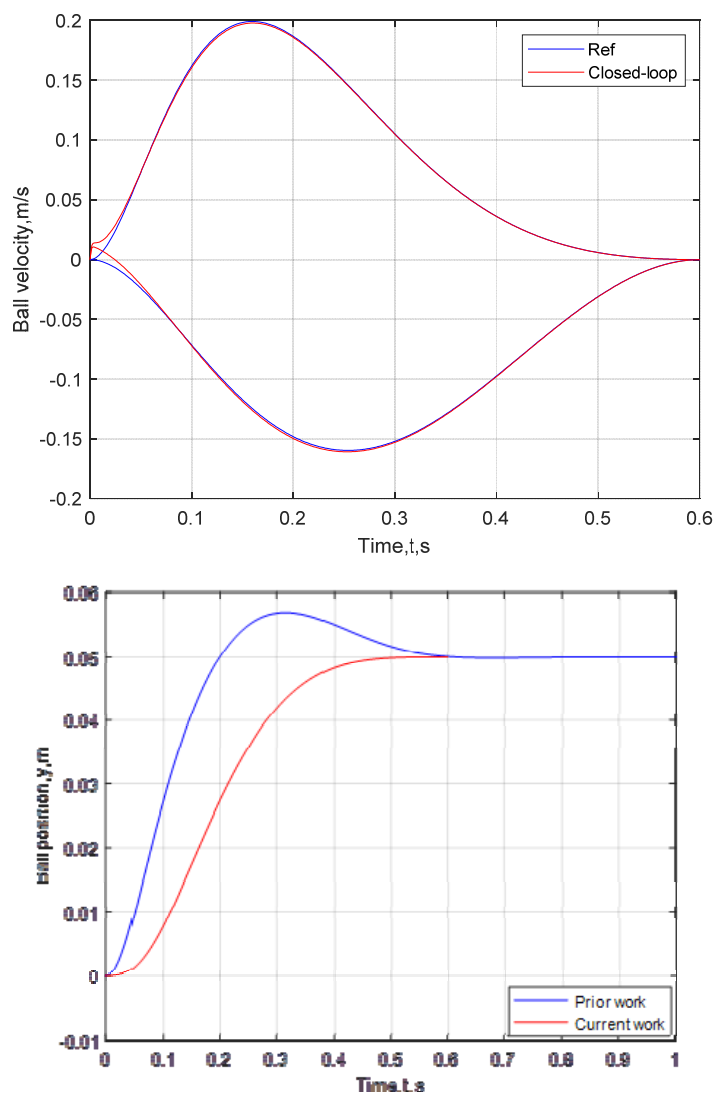

Figure 7. Actual ball position profiles for the current and prior woks); (a) ball position vs. time for $\mathrm{y}_{0}=0 \mathrm{~m}$; (b) ball position vs. time for $y_{0}=0.07 \mathrm{~m}$.

\section{RESULTS AND DISCUSSION}

A Monte-Carlo simulation is a technique that precisely illustrates uncertainties in model states. By using this method, a random value is adopted for each of the trails, relying on range of assessments. The statistics results are stored and the process is repeated several times with dissimilar randomly-adopted values. Recognized statistics results such as the standard deviation, and mean value were applied to dissect the algorithm results as used by [24] and [25].

In this paper, 1000 Monte-Carlo numerical simulations were implemented in order to perform the effectiveness of the proposed algorithm under wide range of initial ball position dispersions. The initial ball position was set uniformly between 0 and $0.1 \mathrm{~m}$.

Figures $8 \mathrm{a}-8 \mathrm{e}$ show the 1000 ball position, ball velocity, coil current, coil voltage, and electrical power histories, respectively. These figures show that the actual profiles track accurately the reference trajectories with using a slight closed-loop effort. Figure 8-a shows that the ball position profiles are bounded between 0 and 0.1 which indicates the ability of the proposed to stabilize the magnetic system while achieving the ball position constraints. Figure 8-d indicates that the maximum and minimum required coil voltage are limited between 0 and 15 Volt, respectively, for all the tested trajectories, thus the magnetic system can remarkably satisfy the steady state position without excessive coil voltage. 


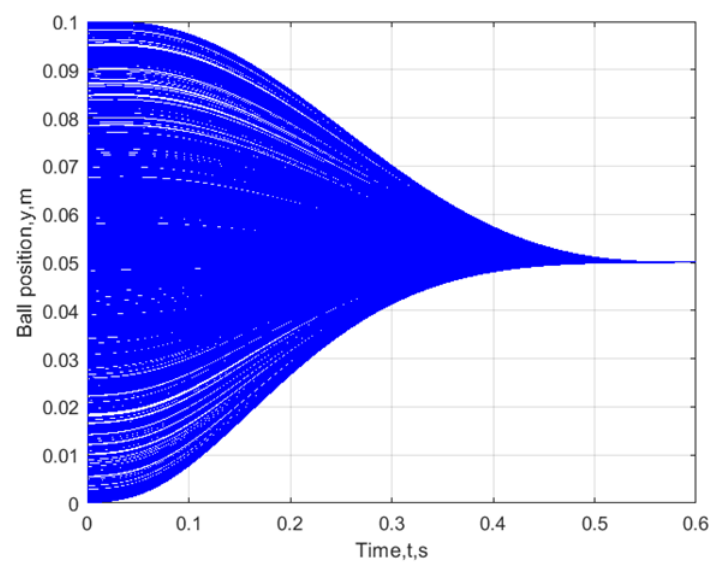

(a)

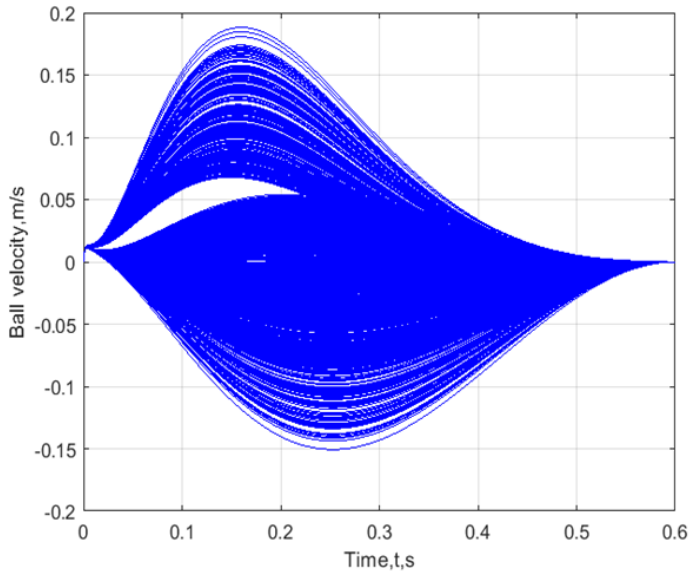

(b)

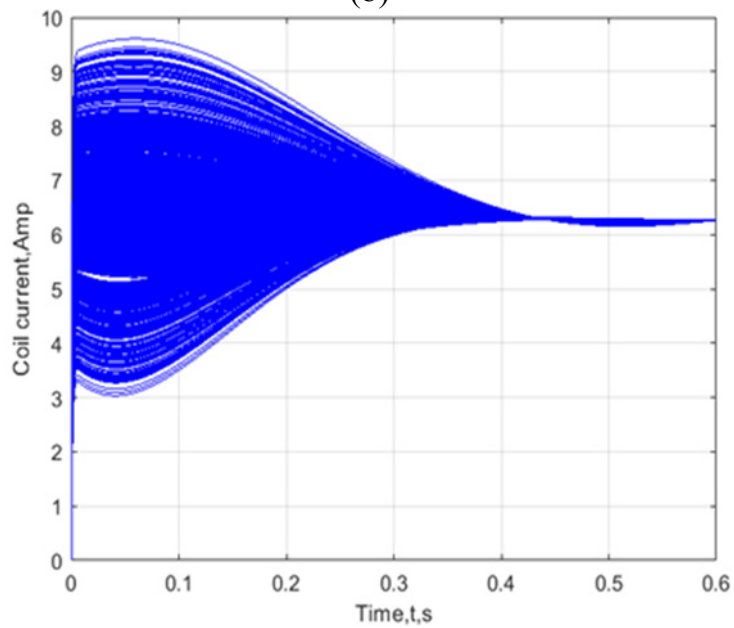

(c)

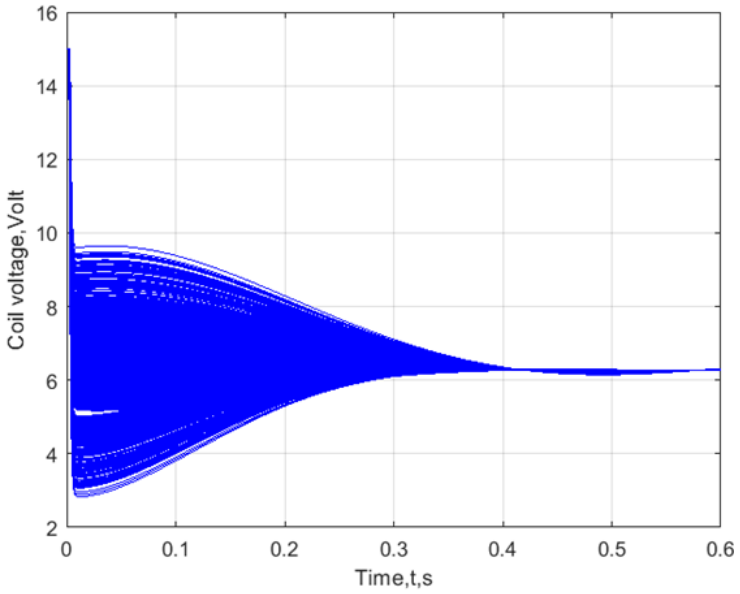

(d)

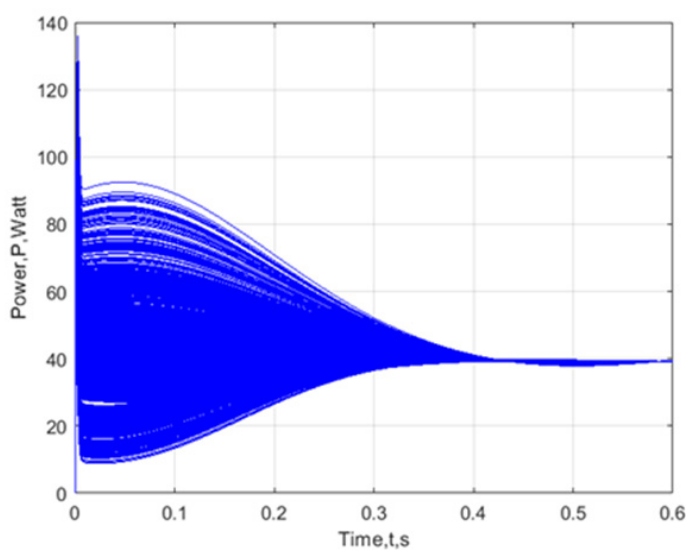

(e)

Figure 8 Magnetic suspension system profiles for 1000 Monte-Carlo trials; (a) ball position vs. time; (b) ball velocity vs. time; (c) coil current vs. time; (d) coil voltage vs. time; (e) electrical power vs. time

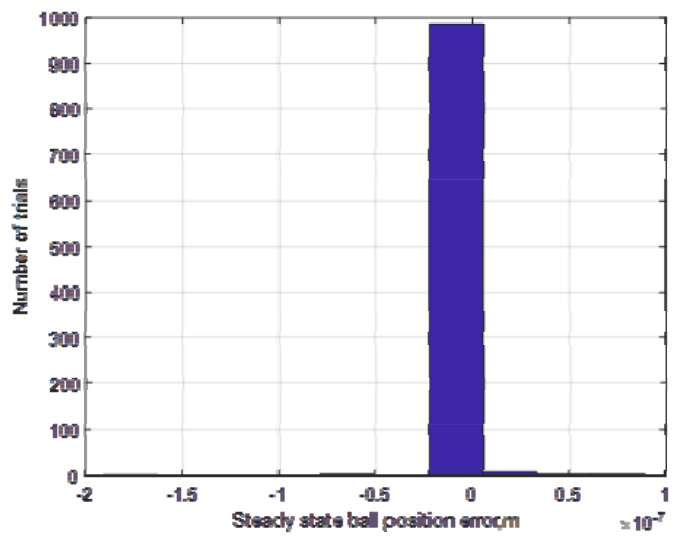

(a)

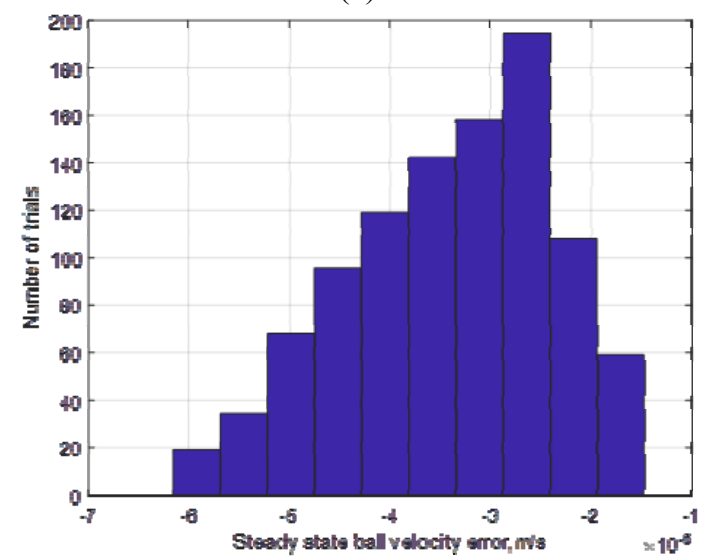

(b)

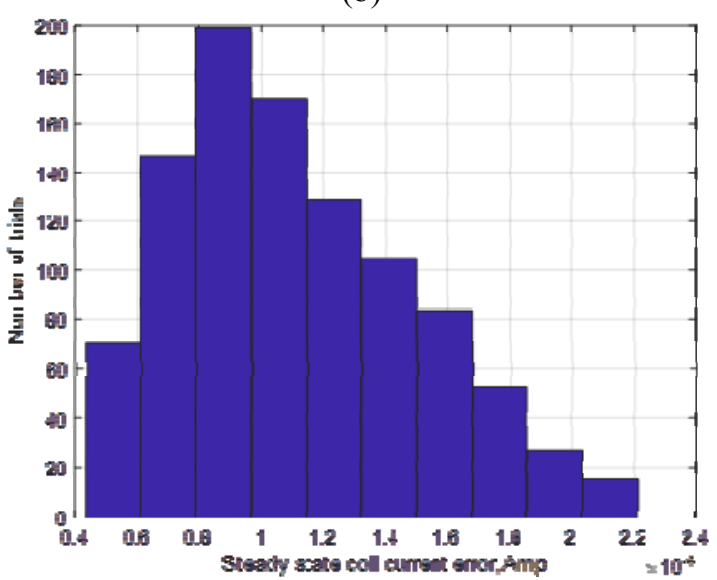

(c) 


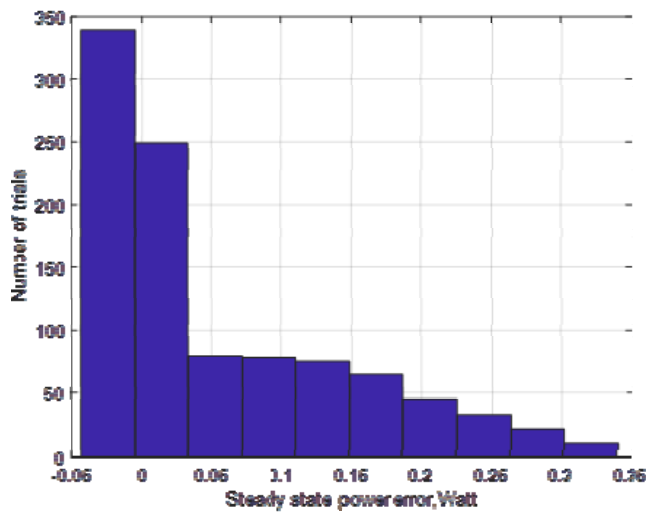

(d)

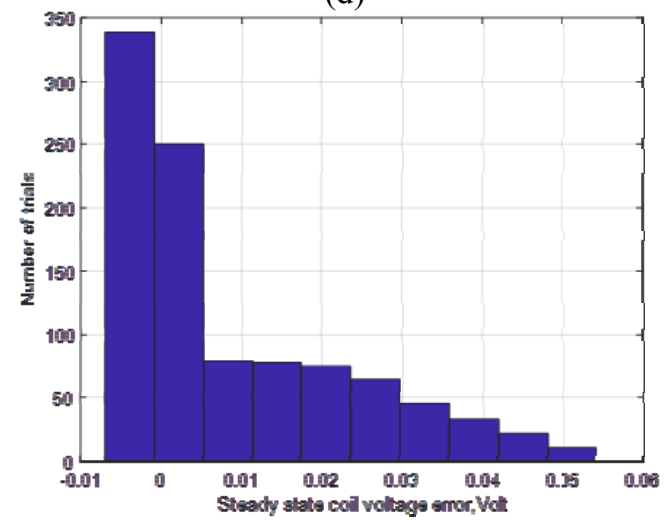

(e)

Figure 9. Histograms of steady-state errors from 1000 Monte-Carlo trials; (a) ball position errors; (b) ball velocity errors; (c) coil current errors; (d) coil voltage errors; (e) electrical power errors

Figures 9-a-9-e show the statistical results of ball position, ball velocity, coil current, coil voltage, and electrical power errors, respectively, at the steady-state position. It can be seen from Fig. 9 that all the steadystate errors are very small. The simulated results of all the steady-state errors are multitude in Table 2.

Figure 9 and Table 2 illustrate a summary of the MonteCarlo tested results. These simulated results indicate that the minimum, maximum, mean, and standard deviation values for the steady-state errors are nearly zero. Hence, the proposed algorithm can greatly ensure reliable performance despite wide initial ball position dispersions.

Table 2 Statistics for steady-state errors.

\begin{tabular}{|c|c|c|c|c|}
\hline State error & Mean & $\begin{array}{c}\text { Standard } \\
\text { deviation }\end{array}$ & Minimum & Maximum \\
\hline $\begin{array}{c}\text { Ball position } \\
(\mathrm{m})\end{array}$ & $1.4\left(10^{-11}\right)$ & $7.9\left(10^{-9}\right)$ & $-1.9\left(10^{-7}\right)$ & $8.9\left(10^{-8}\right)$ \\
\hline $\begin{array}{c}\text { Ball velocity } \\
(\mathrm{m} / \mathrm{s})\end{array}$ & $-3.4\left(10^{-5}\right)$ & $1.2\left(10^{-5}\right)$ & $-6.1\left(10^{-5}\right)$ & $-1.4\left(10^{-5}\right)$ \\
\hline $\begin{array}{c}\text { Coil current } \\
(\text { Amp) }\end{array}$ & $1.1\left(10^{-4}\right)$ & $3.8\left(10^{-5}\right)$ & $4.3\left(10^{-5}\right)$ & $2.2\left(10^{-4}\right)$ \\
\hline $\begin{array}{c}\text { Coil voltage } \\
\text { (Volt) }\end{array}$ & 0.0084 & 0.0143 & -0.007 & 0.054 \\
\hline $\begin{array}{c}\text { Electric Power } \\
\text { (Watt) }\end{array}$ & 0.0534 & 0.0089 & -0.0432 & 0.34 \\
\hline
\end{tabular}

\section{CONCLUSION}

A new analytical algorithm has been developed for the magnetic suspension system. The proposed algorithm employs a six- term exponential function that allows iteration on a single algorithm parameter (exponential factor) such that initial and final states are accurately satisfied while minimizing the peak of electrical power. The closed -loop and the reference ball position profiles do not exceed the interval $\left[\begin{array}{ll}0 & 0.1\end{array}\right]$ for the nominal and off-nominal approaches. The reference profiles have been tracked remarkably with low overshoot, typical steady-state time, and excellent performance characteristics. The obtained results using the MonteCarlo simulation showed that the maximum, minimum, standard deviation, and the mean for the steady-state errors are very small compared to the prior works. That shows the reliability of the new algorithm even for a wide range of ball position dispersions.

\section{REFERENCES}

[1] Hu, S.Y., 2008. Magnetic levitation weight reduction structure for a vertical wind turbine generator. U.S. Patent 7,462,950.

[2] Kumbernuss, J., Jian, C., Wang, J., Yang, H.X. and Fu, W.N., 2012. A novel magnetic levitated bearing system for vertical axis wind turbines (VAWT). Applied Energy, Volume 90, No. 1, pp. 148-153.

[3] Yonnet, J.P., 1978. Passive magnetic bearings with permanent magnets. IEEE Transactions on magnetics, 14(5), pp.803-805.

[4] Schweitzer, G., 2002, October. Active magnetic bearings-chances and limitations. In 6th International Conference on Rotor Dynamics (pp. 1-14).

[5] Tang, J., Wang, K. and Xiang, B., 2016. Stable control of high-speed rotor suspended by superconducting magnetic bearings and active magnetic bearings. IEEE Transactions on Industrial Electronics, 64(4), pp.3319-3328.

[6] Cui, C.Y., Hu, X.N., Cheng, J.S., Wang, H. and Wang, Q.L., 2015. Analysis of magnetic disturbance torque and drift error in a superconducting suspension system. Acta Physica Sinica, 64(1), p.018403.

[7] Yang, Z.J. and Tateishi, M., 2001. Adaptive robust nonlinear control of a magnetic levitation system. Automatica, 37(7), pp.1125-1131.

[8] El Hajjaji, A. and Ouladsine, M., 2001. Modeling and nonlinear control of magnetic levitation systems. IEEE Transactions on industrial Electronics, 48(4), pp.831-838.

[9] Barie, W. and Chiasson, J., 1996. Linear and nonlinear state-space controllers for magnetic levitation. International Journal of systems science, 27(11), pp.1153-1163.

[10] Trumper, D.L., Olson, S.M. and Subrahmanyan, P.K., 1997. Linearizing control of magnetic suspension systems. IEEE Transactions on control systems technology, 5(4), pp.427-438.

[11] Isidori, A., 2013. Nonlinear control systems. Springer Science \& Business Media.

[12] Liu, C., Fu, D. and Wang, T., 2011, August. Hळ control for magnetic suspension system of gantry- 
moving type numerically controlled machine tool crossbeam. In Proceedings of 2011 International Conference on Electronic \& Mechanical Engineering and Information Technology (Vol. 1, pp. 21-23). IEEE.

[13] Kim, Y.H., Jang, J.Y., Jo, H.C., Choi, S., Na, J.B., Lee, C.Y., Song, J.B., Lee, H., Ko, T.K. and Hwang, Y.J., 2012. A study on the loss in a superconducting magnet by the control current in a hybrid electro-magnetic suspension system. IEEE transactions on applied superconductivity, 22(3), pp.3600105-3600105.

[14] Zheng, K., 2014. Control of an Active Magnetic Bearing System during Maneuvering Flight. In 50th AIAA/ASME/SAE/ASEE Joint Propulsion Conference (p. 3852).

[15] Takagi, Y., Sawada, H. and Obayashi, S., 2016. Development of Magnetic Suspension and Balance System for Intermittent Supersonic Wind Tunnels. AIAA Journal, 54(4), pp.1277-1286.

[16] Komori, M., Minoda, A., Nemoto, K. and Asami, K., 2017. Maximum limit of superconducting persistent current for superconducting magnetic suspension system. IEEE Transactions on Magnetics, 53(11), pp.1-4.

[17] Ocokoljić, G., Rašuo, B. and Kozić, M., 2017. Supporting system interference on aerodynamic characteristics of an aircraft model in a low-speed wind tunnel. Aerospace Science and Technology, 64, pp.133-146.

[18] Kai, D., Sugiura, H. and Tezuka, A., 2018. Development of Magnetic Suspension and Balance System for High-Subsonic Wind Tunnel. In 2018 AIAA Aerospace Sciences Meeting (p. 0304).

[19] Ocokoljić, G., Damljanović, D., Vuković, Đ. and Rašuo, B., 2018. Contemporary frame of measurement and assessment of wind-tunnel flow quality in a low-speed facility. FME Transactions, 46(4), pp.429-442.

[20] Ocokoljić, G., Damljanović, D., Rašuo, B. and Isaković, J., 2014. Testing of a standard model in the VTI's large-subsonic wind-tunnel facility to establish users' confidence. FME Transactions, 42(3), pp.212-218.

[21] Damljanović, D., Vuković, Đ., Ocokoljić, G. and Rašuo, B., 2020. Convergence of transonic wind tunnel test results of the AGARD-B standard model. FME Transactions, 48(4), pp.761-769.

[22] Ocokoljić, G., Rašuo, B., Damljanović, D. and Živković, S., 2020. Experimental and numerical research of the influence of thrust vector control on the missile aerodynamics by cold and hot jet simulations. FME Transactions, Volume 48(4), pp. 770-778.

[23] Khalil, H.K. and Grizzle, J.W., 2002. Nonlinear systems (Vol. 3). Upper Saddle River, NJ: Prentice hall.

[24] Fawaz, A.B., Laheeb, M. and Salwan, K., 2018, January. Online algorithm for controlling an inverted pendulum system under uncertainty in design parameters and initial conditions using Monte-Carlo simulation. In 2018 IEEE 8th Annual Computing and Communication Workshop and Conference (CCWC) (pp. 1-7). IEEE.

[25] Laheeb, M., Salwan, K., Fawaz, A.B. and Sarah, L, 2018, January. Online algorithm for controlling a cruise system under uncertainty in design parameters and environmental conditions using Monte-Carlo simulation. In 2018 IEEE 8th Annual Computing and Communication Workshop and Conference (CCWC) (pp. 424-430). IEEE.

\section{NOMENCLATURE}

$\begin{array}{ll}L(y), L_{o}, L_{1} & \text { Magnetic inductance constants } \\ i(t) & \text { Electrical current } \\ m & \text { Mass of the suspended ball } \\ \mathrm{g} & \text { Gravitional acceleration } \\ \mathrm{R} & \text { Circuit resistance } \\ y & \text { Degree of the freedom of the ball } \\ E & \text { Electrical energy of the electrical cicuit } \\ \phi & \text { Magnetic flux } \\ k & \text { Viscous friction } \\ x_{1}, x_{2}, x_{3} & \text { System states } \\ u & \text { System input } \\ A, B & \text { Matrices for linearization } \\ P_{r e f} & \text { Electrical power } \\ v_{r e f} & \text { Reference voltage } \\ \varepsilon & \text { Exponent factor }\end{array}$

\section{НОВА АНАЛИТИЧКА СТРАТЕГИЈА УПРАВЉАЊА СИСТЕМОМ МАГНЕТНЕ СУСПЕНЗИЈЕ У УСЛОВИМА ДИСПЕРЗИЈЕ ПОЧЕТНОГ ПОЛОЖАЈА}

\author{
Ф.Ф. Ал-Бакри, Х.Х. Али, С.О.В. Кафаџи
}

Разматра се нелинеарни систем магнетне суспензије. Приказан је нови онлајн алгоритам за стабилизовање суспендоване масе базиран на аналитичком приступу. Нови алгоритам користи једну аналитичку функцију за креирање положаја лоптице и профила брзине. Референтни положај лоптице описан је низом временски зависних експоненцијалних функција. Гранични услови почетног и коначног стања су аутоматски задовољени. Изводљив положај лоптице и профили брзине су омогућени евалуацијом једног параметра алгоритма (експоненцијалним фактором). Експоненцијални фактор је срачунат аналитичким минимизирањем максималне снаге електричне енергије. Нови алгоритам може да генерише одговарајући напон калема који осигурава стабилност система са командом мале затворене петље. GS метод се користи за утврђивање тежње затворене петље да прати аналитички референтне профиле. У поређењу са раније развијеним алгоритмима за магнетну суспензију предложена аналитичка шема може да манипулише великим дисперзијама почетног положаја лоптице, при чему се задовољавају ограничења положаја лоптице и напона калема. Приказана је Монте-Карло 
симулација са променом почетног положаја лоптице. Резултати симулације показују високу поузданост предложеног алгоритма упркос великој дисперзији почетног положаја лоптице. 